Valley of Mexico, which was a richly wooded zone when the white men came. Charcoal, the great fuel of modern Mexico, has been made at the expense of the forests, and the first wood-burning railroads and timber-cutters of mines destroyed forests in many regions. Modern regulations require miners to get permission to cut timber, and to plant new trees for every old one cut."

\section{Soldering and Brazing}

THE issue of the Journal of Scientific Instruments for November contains an illustrated article on soldering and brazing by A. S. Newman and Dr. R. S. Clay, which will be found most useful by workers in scientific laboratories. It describes the conditions under which soft and hard soldering can be carried out most successfully, the best fluxes to use, and the proper way to apply them and the solder. Special methods for tubes and for manganin wires are described, and handy forms of burners, clamps and cutting tools are shown.

\section{Dairy Herd with a Long History}

THE dairy herd of the Cornell University has been in existence for more than forty years, and a full history of it has been issued by the Cornell University Agricultural Experiment Station. Ithaca, N.Y. (Bull. 576). The pure-bred Holstein-Friesians of the herd, the descendants of one cow, "Glista", are noteworthy, and "Glista Ernestine" the most remarkable individual. Born in 1908, she died at the age of sixteen years, having produced thirteen calves, all of which except one reached maturity. She was amiable and affectionate and always healthy, and her average yearly production of milk reached the remarkable total of 14,878 pounds.

\section{Announcements}

IT is announced in Science of November 17 that Mr. Knowles A. Ryerson has been appointed chief of the U.S. Bureau of Plant Industry as from January 1, in succession to Dr. W. A. Taylor who retires after forty-two years' service with the Department of Agriculture.

The Council of the Iron and Steel Institute is prepared to make annually a number of grants from the Andrew Carnegie research fund in aid of metallurgical research work. The object of the scheme is to enable students who have passed through a college curriculum or have been trained in industrial establishments, to conduct researches on problems of practical and scientific importance relating to the metallurgy of iron and steel and allied subjects. Candidates, who must be less than thirty-five years of age, must apply before the end of next February on a special form to be obtained from the Secretary of the Institute. The value of the grant will depend on the nature of the proposed research work, but the maximum amount granted in any one year will, as a rule, not exceed £100. Further information can be obtained from the Secretary, Iron and Steel Institute, 28, Victoria Street, London, S.W.1.
The annual Congress of the Royal Institute of Public Heath will be held at Norwich on May 15-20, 1934, under the presidency of Alderman H. N. Holmes. The Congress will be divided into five sections: State medicine and industrial hygiene; women and children and the public health; tuberculosis; veterinary medicine and agriculture; pathology and bacteriology. Further information can be obtained from the Secretary, Royal Institute of Public Health, 23 Queen Square, London, W.C.1.

THe fourth International Congress of Radiology will be held at Zurich on July 24-31, 1934, under the presidency of Prof. H. R. Schinz. At this meeting Prof. Gosta Forssell will report on the organisation of cancer campaigns in general. Other speakers will report upon the measures in their own countries. The programme includes the discussions on various medical aspects of radiology, radiation genetics, mitogenetic radiation, structure analysis, identical physical measurement of the dose in X-ray and radium treatment, hard gamma-rays, cosmic radiation, earth radiation. Further information can be obtained from Dr. H. E. Walther, secretary of the Congress, Zurich, Gloriastrasse, 14.

Applications are invited for the following appointments, on or before the dates mentioned :- Two temporary civil engineering assistants for the Directorate of Works, War Office-The Under-Secretary of State (C.5), The War Office, London, S.W.1 (Dec. 11). An executive engineer in the Public Works Department, Electricity Branch, of the Government of the Punjab-The High Commissioner for India, General Department, India House, Aldwych, London, W.C.2 (Dec. 15). A junior investigator for the Royal Commission on Historical Monuments (England)-The Secretary, 29, Abingdon Street, London, S.W.1 (Dec. 16). An assistant vocational guidance officer for the Kent Education Committee-The Director of Education, Springfield, Maidstone (Dec. 16). An assistant education officer (general purposes) for the London County Council--The Education Officer (Establishment), County Hall, London, S.E.l (Dec. 16). A junior assistant (woman) in the Science Museum LibraryThe Director, Science Museum, South Kensington, London, S.W.7 (Dec. 21). A Leon fellow for research (preferably economics or education) in the University of London-The Principal, University of London, South Kensington, S.W.7 (Jan. I). A marketing expert to advise the Imperial Council of Agricultural Research in India-The High Commissioner for India, General Department, India House, Aldwych, London, W.C.2 (Jan. 1). A research assistant to the Burden Mental Research Trust for work at Stoke Park Colony, Bristol-The Secretary, B.M.A. House, Tavistock Square, London, W.C.l (Jan. 9). A headmaster of the Secondary School, The Polytechnic, Regent Street, London, W.C.I-The Director of Education (Jan. 20). An assistant chemist in the Research Department of the South Eastern Agricultural College, Wye, Kent-The Secretary. 